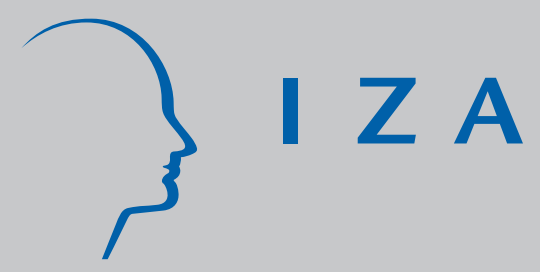

IZA DP No. 1217

Immigration Policy:

Methods of Economic Assessment

Don J . DeVoretz

July 2004 


\title{
Immigration Policy: \\ Methods of Economic Assessment
}

\author{
Don J. DeVoretz \\ RIIM, Simon Fraser University \\ and IZA Bonn
}

Discussion Paper No. 1217

July 2004

\author{
IZA \\ P.O. Box 7240 \\ 53072 Bonn \\ Germany \\ Phone: +49-228-3894-0 \\ Fax: +49-228-3894-180 \\ Email: iza@iza.org
}

\begin{abstract}
Any opinions expressed here are those of the author(s) and not those of the institute. Research disseminated by IZA may include views on policy, but the institute itself takes no institutional policy positions.

The Institute for the Study of Labor (IZA) in Bonn is a local and virtual international research center and a place of communication between science, politics and business. IZA is an independent nonprofit company supported by Deutsche Post World Net. The center is associated with the University of Bonn and offers a stimulating research environment through its research networks, research support, and visitors and doctoral programs. IZA engages in (i) original and internationally competitive research in all fields of labor economics, (ii) development of policy concepts, and (iii) dissemination of research results and concepts to the interested public.
\end{abstract}

IZA Discussion Papers often represent preliminary work and are circulated to encourage discussion. Citation of such a paper should account for its provisional character. A revised version may be available on the IZA website (www.iza.org) or directly from the author. 


\section{ABSTRACT}

\section{Immigration Policy: Methods of Economic Assessment*}

This paper outlines a set of economic criteria to assess an immigrant receiving country's immigration policy from three perspectives. These three perspectives include the resident population, the immigrant and the sending country viewpoints. An expanded version of Julian Simon's financial transfer model which includes employment and capital externalities is developed to assess the efficacy of an immigration policy from the resident's viewpoint. Next, Chiswick's earnings "catch-up" model is expanded in an employment dimension to create an assessment criterion for the resident immigrant population. Finally, a comprehensive reverse transfer criterion is outlined to provide an assessment criterion for sending regions. These criteria are then applied to European and North America immigrant receiving countries.

JEL Classification: J68

Keywords: immigration workers, public policy

Don J. DeVoretz

RIIM

Simon Fraser University

Burnaby, BC, V5A 1 S6

Canada

Email: devoretz@sfu.ca

\footnotetext{
* This paper is dedicated to the memory of Julian Simon and his intellectual legacy. The generous support provided by the Willi Brandt Professorship at IMER, Malmö University and grants from RIIM, Vancouver's Centre of Excellence, Simon Fraser University and IZA, Bonn allowed me time to write this paper. The research assistance of S. Pivnenko is noted with appreciation. Comments by $\mathrm{F}$. Vadean, D. Coulombe and M. Spang improved the paper.
} 


\section{Introduction}

The opening of the $21^{\text {st }}$ century has witnessed continuing controversies over how nation states should react to potential immigrant flows and the seeming inability of immigrants to integrate into the receiving state. Examples of paradoxical immigrant admission policies abound. Faced with continued post NAFTA (1995) inflows of unskilled Mexican immigrants, the United States reacted by limiting immigrant access to social benefits. Then a few years later, in 2004, President Bush offered a temporary green card to legalize undocumented Mexican immigrants and regularize their labour market status. The European Union circa 2003-2004 acted in a similarly confused manner with respect to the prospect of increased migration flows from newly ascending members.

Generous and liberal migration policies were initially offered by some member states, like Sweden, England and Ireland to the newly ascended member states. On the other hand, less generous mobility terms were offered to Poland by Germany and Austria. As the ascension date drew near, generous migration policies announced previously became more restrictive with stringent economic conditions attached to the mobility rights of new member states. ${ }^{1}$ In other parts of the world, a few traditional immigrant-receiving countries, Canada and Australia, maintain a relatively open and aggressive immigration policy.

As economists, how are we to judge the economic successes or failures of these various restrictive or more generous immigration regimes? Does there exist a set of general economic principles that can guide us in this assessment? Or is the world so idiosyncratic that each state has its own implied social welfare function such that economics cannot guide us? The purpose of this lecture is to search for some general economic principles to assess a country's immigration policy from three viewpoints: the immigrant-receiving country's, the immigrant's and the sending region's.

It would be instructive at this point to consider the implications of finding a set of mutually agreed upon economic criteria to evaluate a destination county's immigration policy. If the opponents of any nation state's immigration policy agree that a common set of economic criteria for immigration admission have been met, but no further immigration is warranted, then these critics must search for a further rationale to reject new immigrants. In other words, critics of immigration cannot use an economic rationale to mask their aversion to further immigrant inflows, and more chauvinistic reasons must be sought to articulate their antipathy to immigrants.

\section{Three Theoretical Perspectives}

\section{A. Host Country Economic Criteria: The Simon Principle}

Simon (1984) articulated the first and perhaps most controversial economic assessment criteria of a nation state's immigration policy. The proposition is as follows:

If the marginal immigrant makes a non-negative contribution to the treasury you continue to admit immigrants until the contribution goes to zero.

This rule has many staunch liberal and conservative supporters. In the liberal or republican state (Sicakkan, 1999), immigrants are acceptable if they confer a net economic benefit on the host country's residents. From a more conservative view, Milton Friedman has argued that the host population should have no interest in the number of arrivals if there exists no welfare state. Thus the political extremes agree on the Simon Principle. ${ }^{2}$

\footnotetext{
${ }^{1}$ Sweden has had three policy positions with respect to Polish mobility and ascension to the European Union. In 2002 Sweden granted full mobility rights to Poland, then withdrew them in early 2004. On May 3rd, 2004, two days after Polish ascension to the European Union, Sweden restored full mobility rights for Poles to enter Sweden.

2 Sicakkan (1999) argues that some extreme forms of the nation states, including ethnically-based states, have such an aversion to immigrants that no economic criteria exists to rationalize their presence.
} 
Is it however legitimate to ask if the Simon Principle for immigrant admission is symmetrical? In other words, if immigrants make a positive and growing public finance contribution, will the nation state admit more immigrants? Finally, one may ask how relevant this rule is. Has any country invoked the Simon Principle to guide its national immigration policy? Two modern examples come to mind. First, the United States has indirectly invoked the Simon Principle to deny public financing to immigrants. Thus, the United States' response to limit immigrant benefits is an indirect recognition of the Simon Principle. In a similar fashion most members of the European Union have invoked the Simon Principle by reducing mobility rights of newly ascended members and denying them access to social benefits. At the other extreme, Canada has historically used the Simon Principle to rationalize an expanding immigration policy. ${ }^{3}$

The theoretical underpinning of the Simon Principle relies on the observation that the native-born and the foreign-born life-cycle tax payments and consumption of public services are respectively concave and convex over the life cycle. Figures 1 and 2 present an optimistic and a pessimistic case.

\section{Figure 1: Age-Consumption-Tax Profiles by Birth Status: Optimistic Case}

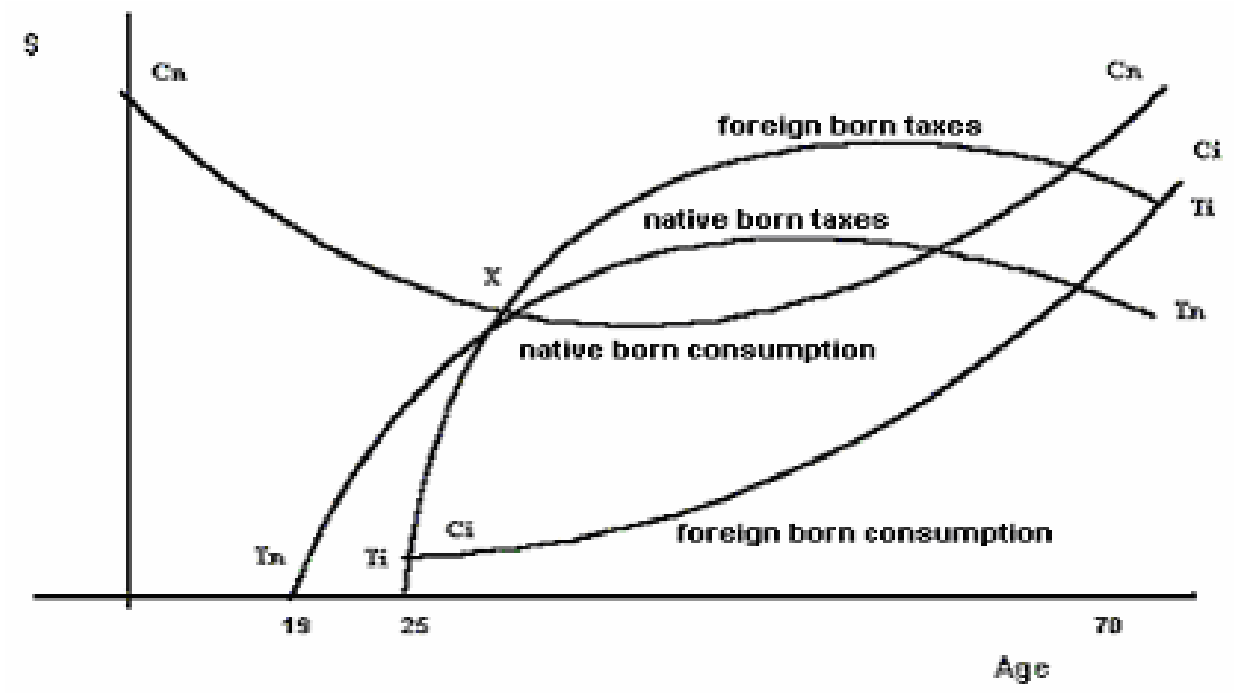

The optimist case imbedded in figure 1 portrays several other properties. First, both the foreign-born and resident-born populations make a net contribution to the treasury. In this optimistic case the foreign-born contribution may be greater than the resident for two reasons. First, the foreign-born tax curves lie everywhere above the foreign-born consumption curve. Moreover, the foreign-born consumption curve starts later than the native-born consumption curve since immigrants arrive later in life. The delayed use of public services coupled with the convex nature of consumption and the existence of a positive discount rate lead to the following proposition:

Intensive foreign-born consumption of public goods occurs at the end of the immigrant's economic life while there exists intensive consumption of public goods at both ends of the life cycle for the native-born population.

\footnotetext{
3 Canada's 1978 Immigration Act specifies three reasons for the admission of immigrants, compassion, family reunification and economic growth. However, the fact that immigrants make a net positive contribution to Canada's treasury has been a guiding principle in reworking the mix of Canada`s immigrant flow to favor a growing class of economic immigrants.
} 
In addition an important corollary follows from the conditions portrayed in figure 1:

If the conditions portrayed in figure 1 hold, then there is a net financial transfer from the foreign-born to the native-born resident.

In fact, given the above observation about the convex (concave) nature of the consumption (tax) curves, then only the intercepts of the tax and consumption curves determine if either population is ultimately a net contributor to the treasury.

Figure 2, the pessimistic case, portrays the consequence on the direction of the public finance transfer of a move in the intercepts. The results of figure 1 are reversed by reducing the earning capacity of the foreign born, which in turn will simultaneously raise their public goods consumption curve whilst lowering the tax payments curve. Now the foreign-born act as a drain on the treasury and are subsidized by the native-born.

\section{Figure 2: Age-Consumption-Tax Profiles by Birth Status: Pessimistic Case}

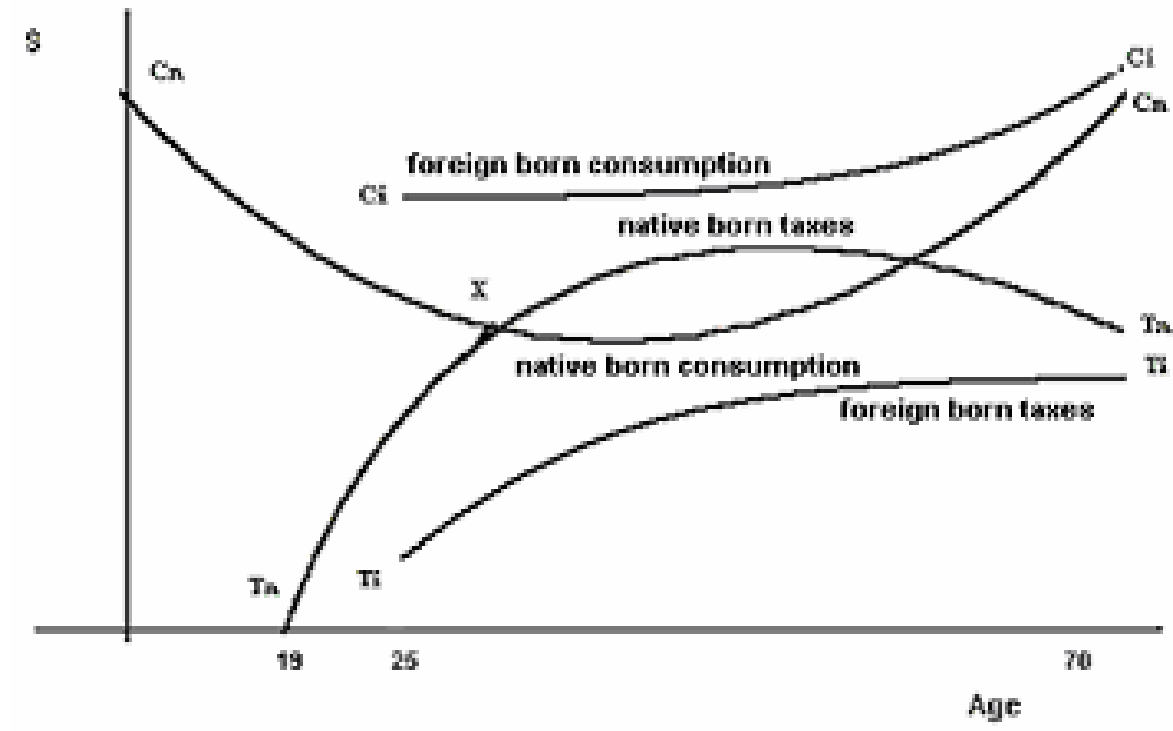

There exist many caveats to the static presentation inherent in figures 1 and 2, including the difficulty in treating true public goods when non-exclusion reigns. In particular researchers have difficulty assigning the costs of pure public goods (public safety, military) on the margin to the newly arrived immigrant (Akbari, 1995). ${ }^{4}$ Moreover, the possible dynamic nature of the problem requires a more complicated overlapping generation's model.

We now turn to consider some evidence and the policy conclusions that flow from the Simon Principle in the North American and European contexts.

Given the dominance of economic immigrants in Canada's recent immigrant inflows, a variation of figure 3 is Canada's most often reported outcome (DeVoretz and Pivnenko, 2004). Given the optimistic outcome under which immigrants make a positive contribution to Canada's treasury, policy makers have argued to increase Canada's immigrant inflow to $1 \%$ of its base population, or 300,000 yearly immigrants in the 1990's. ${ }^{5}$ The opposite argument was made in the United States context circa 1997. In the 1990's, evidence was offered that immigrants to the United States caused a negative treasury transfer (Smith and Edmonston, 1997) similar to figure

\footnotetext{
${ }^{4}$ This difficulty arises since the marginal cost is zero with a pure public good, and it is impossible to exclude consumption by the marginal immigrant.

${ }^{5}$ Currently the annual inflow of immigrants is less than 250,000 per year.
} 
2. The exact immigrant burden on the United States treasury varied by study area, with immigrants in New Jersey imposing a negative fiscal impact of $\$ 166$ per native household while in California the negative impact was estimated to be $\$ 226$ per native household.

Figure 3: Tax payments Versus Government Transfers for Foreign-born by Age, All Canada 1989-1997 (5-year moving average, 1992 dollars

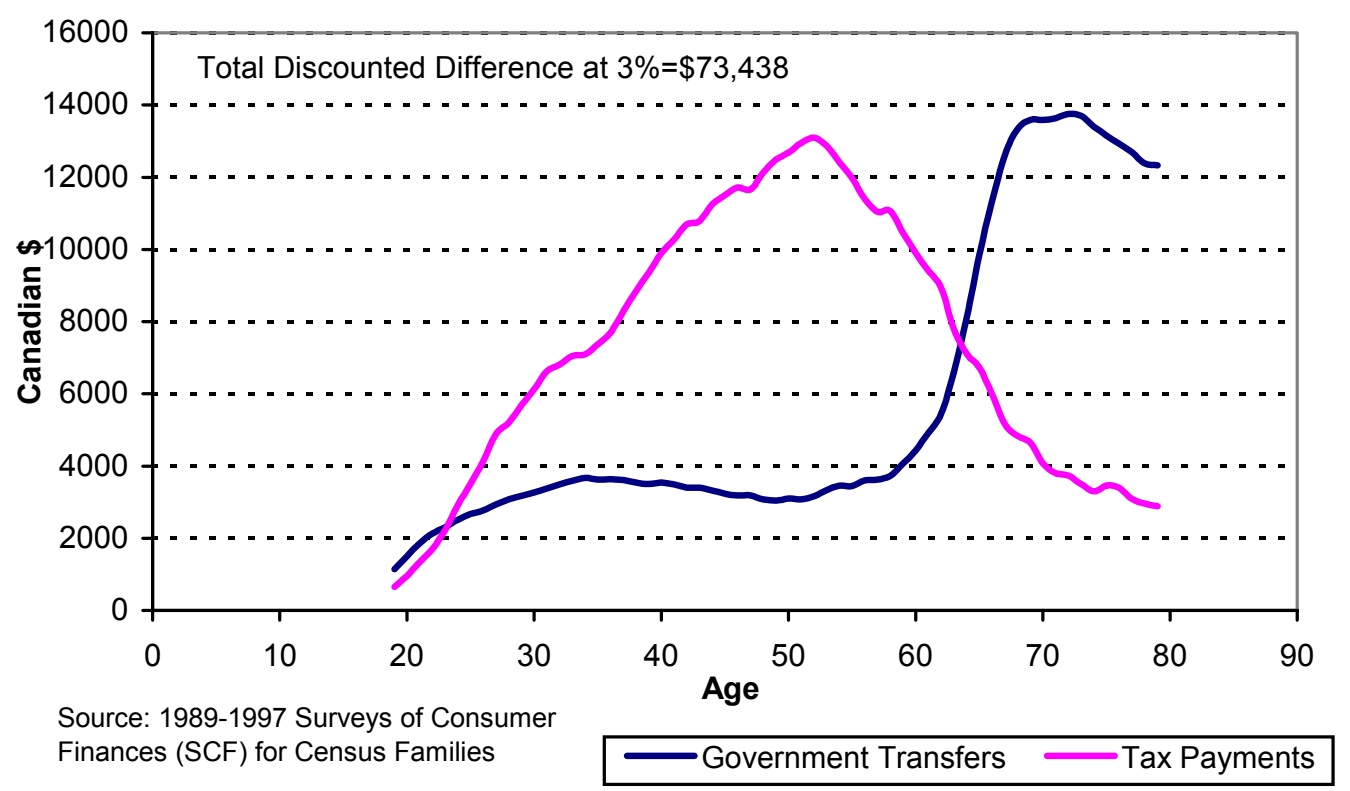

The United States acted upon this evidence not by reducing the number of legal immigrants it admitted, but by attempting to reverse the outcome of the treasury burden calculations circa 1997. A series of United States state laws were initially passed to prohibit immigrants and their children from securing a series of state-sponsored health and education benefits. Then with the overhaul of the United States welfare laws, immigrants were excluded from all federally-financed benefits until ascension to citizenship (Boras, 2003). Thus, in effect United States federal policy responded indirectly to the Simon Principle by removing the presumed welfare magnet portion of the publicly-financed transfers and lowering the public consumption goods curve as portrayed in figure $2 .^{6}$

Germany and Sweden represent two prototypical European cases to explore the Simon Principle. Germany has had very large immigrant inflows as guest workers, asylum seekers and reunited family members. ${ }^{7}$ While more modest, Sweden's immigrant programmes are primarily geared to refugee claimants. Both countries have a progressive tax structure and an extensive welfare state. The immigrant fiscal transfers in either case would then ultimately depend on immigrant employment opportunities given rigid labour markets (Bevelander, 2000). ${ }^{8}$

In the Swedish case (Figure 4), a version of Simon's theoretical life cycle model holds for both Swedish-born and foreign-born residents circa 1992. In other words, the public finance

\footnotetext{
${ }^{6}$ Lofstrom and Bean, (2002) argue that state-financed immigrant benefits substituted for the immigrant exclusion from federal benefits.

${ }^{7}$ There were 7.3 million foreign-born residents in Germany in 2002 (U.N. 2002).

${ }^{8}$ Bevelander (2000) argues that the economic performance of a Swedish immigrant depends on being employed since wages are inflexible downward.
} 
transfer function is concave with a small surplus appearing during part of the household's working life. In fact, for the representative Swedish foreign-born household circa 1992, a positive public transfer begins to appear approximately at age 30 and continues until about age 65 . The Swedish-born household's contribution begins at an earlier age (25) for the male head of household, and is more pronounced but also declines to a zero transfer at age 65. As reported by Gustafson and Osterberg (2001), the undiscounted transfer for the representative foreign-born household circa 1992 obtains a relatively small negative value of 11,272 (SEK 1990 prices).

Figure 4: Swedish Public Finance Transfers by Birth Status: 1992

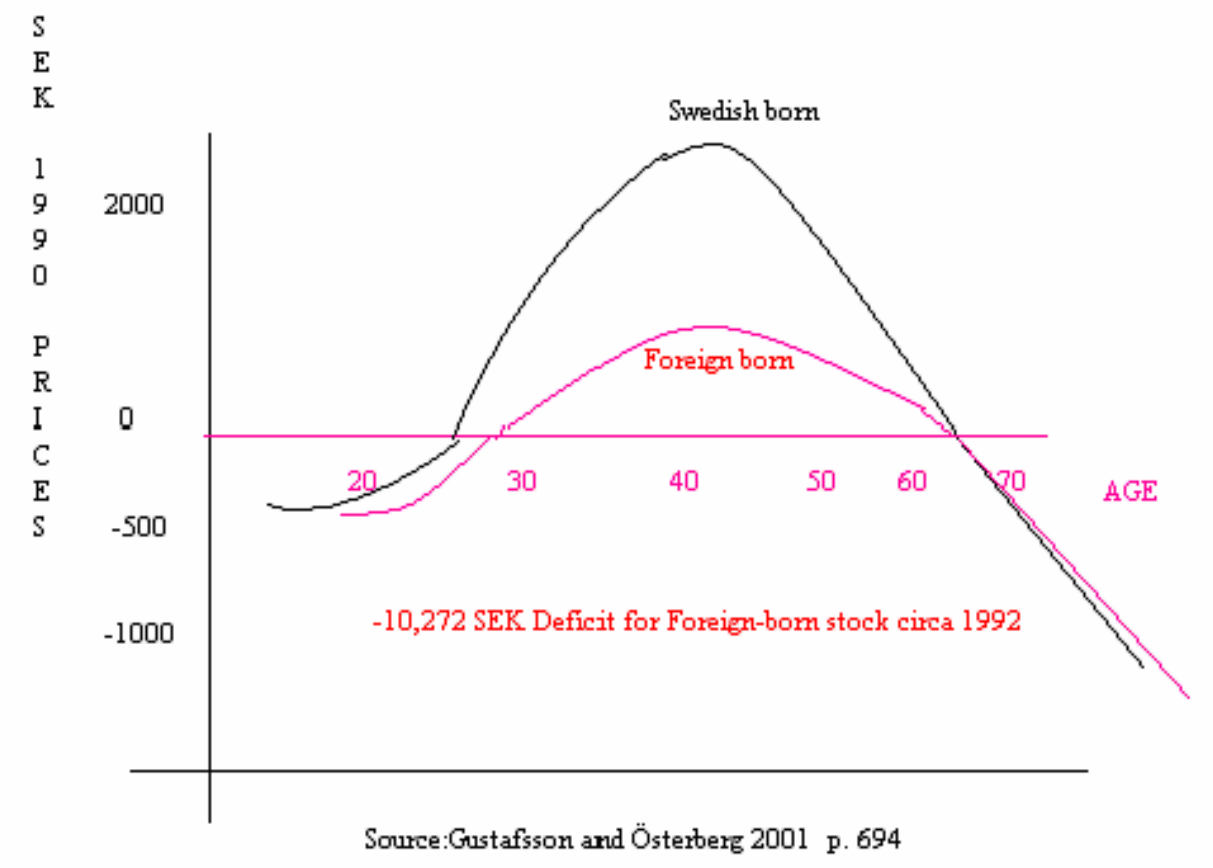

The concave shape of the Swedish public transfers indicates that if a small public finance deficit occurs, as happened in 1992, the remedy to reinstate the Simon Principle is straightforward: foreign-born income must rise faster or publicly-financed consumption items must be reduced, or both. In other words, the Swedish case is not analytically different than the Canadian (or any other documented) case except that the foreign-born transfer is marginally negative.

Figure 5 indicates how sensitive the Swedish foreign-born public transfer results are to two key conditioners, education and visa status. If Swedish refugees had the minimum (or compulsory) level of education in 1992, then their public finance transfers would have been negative for almost their entire life. On the other hand, if the Swedish foreign-born residents were admitted as non-refugees with a university education, then the public finance transfers exceed the average Swedish-born contribution by a three-fold margin (see figure 4). However, the refugee portion of the Swedish population did not make a positive transfer (Figure 5) and this led to calls for the limitation on the admission of any foreign-born, including the new European Union 
members. ${ }^{9}$ Thus, given this evidence, Swedish policy makers and critics of the Swedish foreignborn population have employed the Simon Principle to rationalize their vacillating immigrant admission policies.

\section{Figure 5: Swedish Public Finance Transfers by Visa and Education Status}

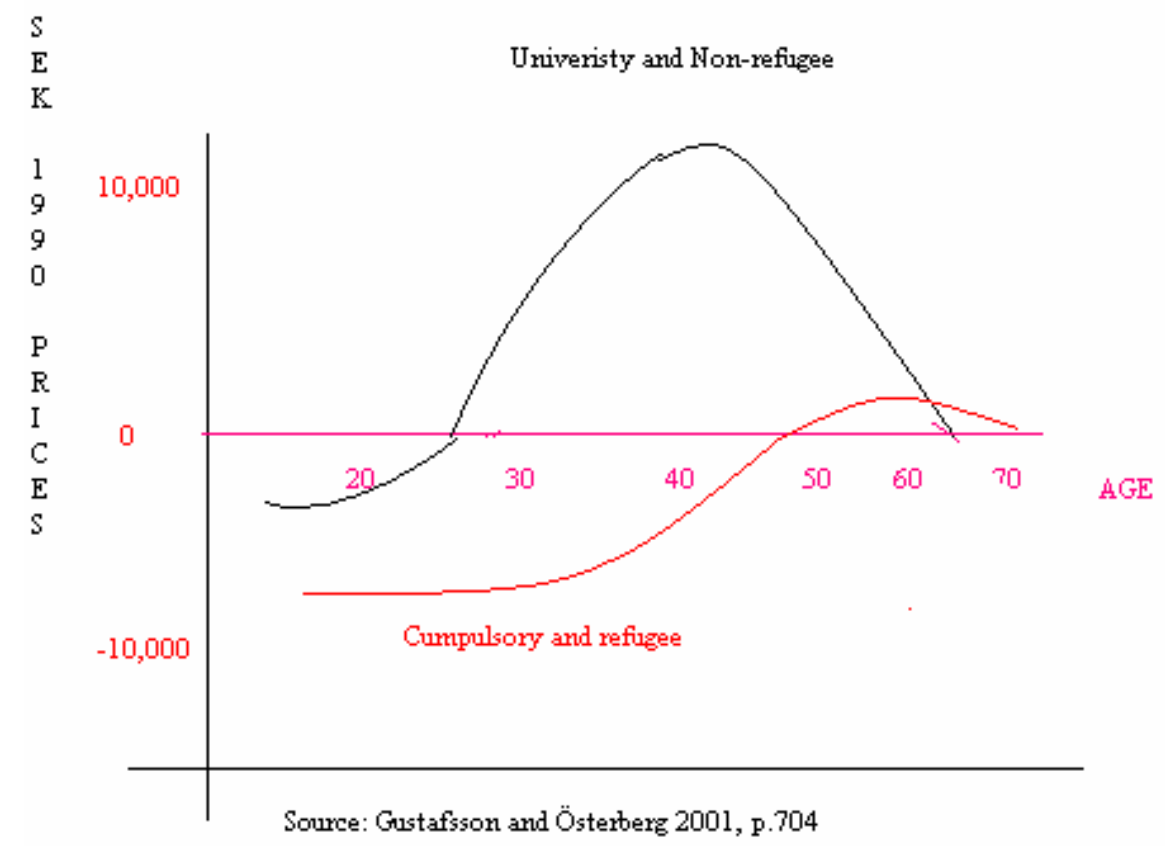

Figure 6 reports the work of Simon and Akbari (2000) in Germany for immigrant public finance transfers under optimistic and pessimistic sets of assumptions, with the usual caveats concerning the omission of some public goods (defense, infrastructure). The German foreignborn population circa 1990 satisfied the Simon Principle under either set of assumptions used by Simon and Akbari. However, given the debate surrounding the introduction of the German Immigration Act, it is clear that no consensus has emerged on the public finance contribution of Germany's immigrants with more modern data.

\footnotetext{
${ }^{9}$ Simulated net present values for ages 25-64 indicate that unmarried male refugees with less than Gymnasium level education have a negative impact on the Swedish treasury of 130,000 to 570,000 Swedish Krona in the 1983-92 period.
} 
Figure 6: German Public Finance Transfers

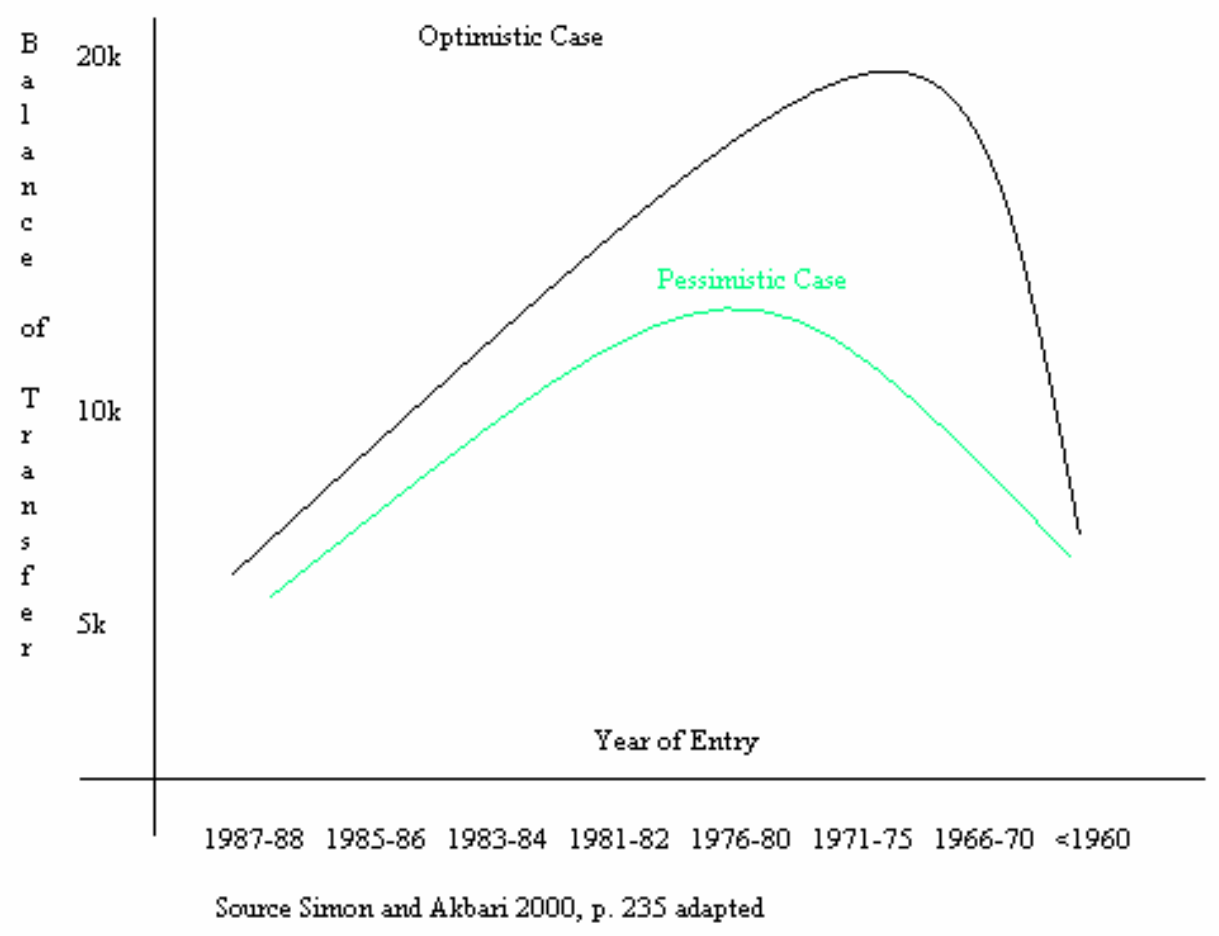

This review illustrates the robustness of the life cycle theory of immigrant public finance transfers across a variety of immigrant-receiving countries in North America and Europe. The size and direction of the public finance transfers depend on the type of immigrant admission policy in a given country and on the presence or absence of a welfare state.

\section{B. Host Country Economic Criteria: Externalities}

In the spirit of the Simon Principle we can continue to pursue economic impacts that may affect the host country's population beyond the pure pecuniary affect of treasury transfers. In fact, there are several potentially important externalities in the labour and capital markets, as well as demographic externalities owing to scale effects which may affect the host country's production function. We review these effects below and argue at this point that any or all of these externalities can potentially offset or complement the treasury transfers noted above.

\section{Labour Market}

The effects of globalization on host country job opportunities have become the issue of the day. The concern is that jobs will either be exported to low-wage countries or that immigrants will replace labour in the destination country. ${ }^{10}$ In this section we concentrate on the immigrant displacement effect in the destination country.

The most naive analysis is predicated on the fallacious concept of "a lump of jobs", i.e., there exist a fixed number of jobs in the immigrant-receiving country. If immigrants are employed, then, by definition, someone must lose their job. In fact, as figure 7 illustrates, in a

\footnotetext{
${ }^{10}$ The best example of this substitution, or out-sourcing jobs, versus immigration is in the United States IT sector. If IT workers are not imported as immigrants, capital and jobs flow to India.
} 
dynamic setting it is possible that immigrants may prove complements and not substitutes to home labour. In figure 7, the receiving country has initially no immigrants, and the equilibrium is at (oe), or full employment, of nationals with a wage of $\left(\mathrm{O}-W_{c}\right)$.

\section{Figure 7: Displacement: Neutral Case}

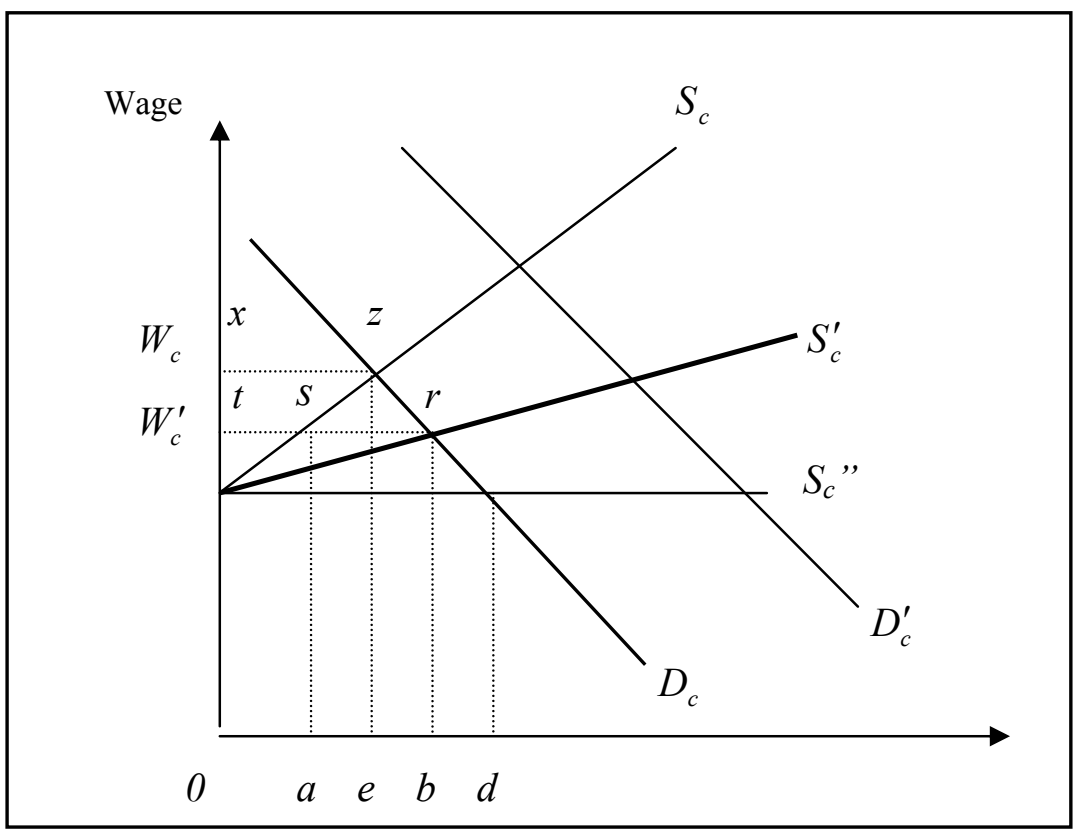

Opening of the labour market to immigrants causes the supply curve of labour to shift everywhere to the right to $\left(S_{c}^{\prime}\right)$ given an entry quota of (a-b) foreigner workers. ${ }^{11}$ This introduction of (a-b) foreign labour initially lowers the home country's wage and displaces (a-e) domestic workers.

We note two further effects. First, total GDP rises as more labour (b-d) is employed in the destination country. ${ }^{12}$ Moreover, if workers bring with them complementary human or financial capital, then the labour demand curve will shift out to the right to $\left(D_{c}^{\prime}\right)$, and this in turn will raise the wage rate and increase the demand for resident labour. In sum, in this particular case, the number of jobs created by the presence of immigrants just offsets the displacement of jobs in the aggregate if we incorporate favourable dynamic effects. We must however be careful to recognize that, even in this neutral case, there is a "churning effect". This effect arises since (a-b) nativeborn workers were initially displaced as immigrants entered the host country's labour force, and only the long-run demand effects offset the initial job displacement of (a-e).$^{13}$ Moreover, the (a-b) workers who initially lost their jobs may not be employed as a result of the later labour demand curve shift. ${ }^{14}$ We return to this concept of churning costs later when discussing the political economy dimension of immigration policy formulation.

\footnotetext{
11 In the extreme, $\left(S_{c}\right.$ ") would be the new supply curve with no immigration quota. Here the displacement of home labour will be complete with $(\mathrm{O}-\mathrm{d})$ foreign labour in figure 4.

12 This is the so-called Harberger triangle.

13 See Akbari and DeVoretz (1992) for an illustration of this case.

14 The (a-b) workers may be of a different skill level and never receive their jobs back. Instead new native-born workers receive the created jobs.
} 
Figure 8 represents an extreme case of near total displacement under which (OA) nativeborn workers initially work for $\bar{W}_{C A D}$ prior to the arrival of any immigrants. However, given a growing demand for labour from $L_{D}$ to $L_{D}^{\prime \prime}$, only foreign workers are hired since they will supply their labour at a lower wage than the domestic workers. Figure 8 is often the case cited when unskilled workers legally or illegally enter and work for a lower wage than the marginal nativeborn worker in the service sector (Chiswick, 2000). Native-born workers are not displaced but the sector is eventually dominated by foreign low-cost labour. ${ }^{15}$

Figure 8: Displacement: Negative Effect

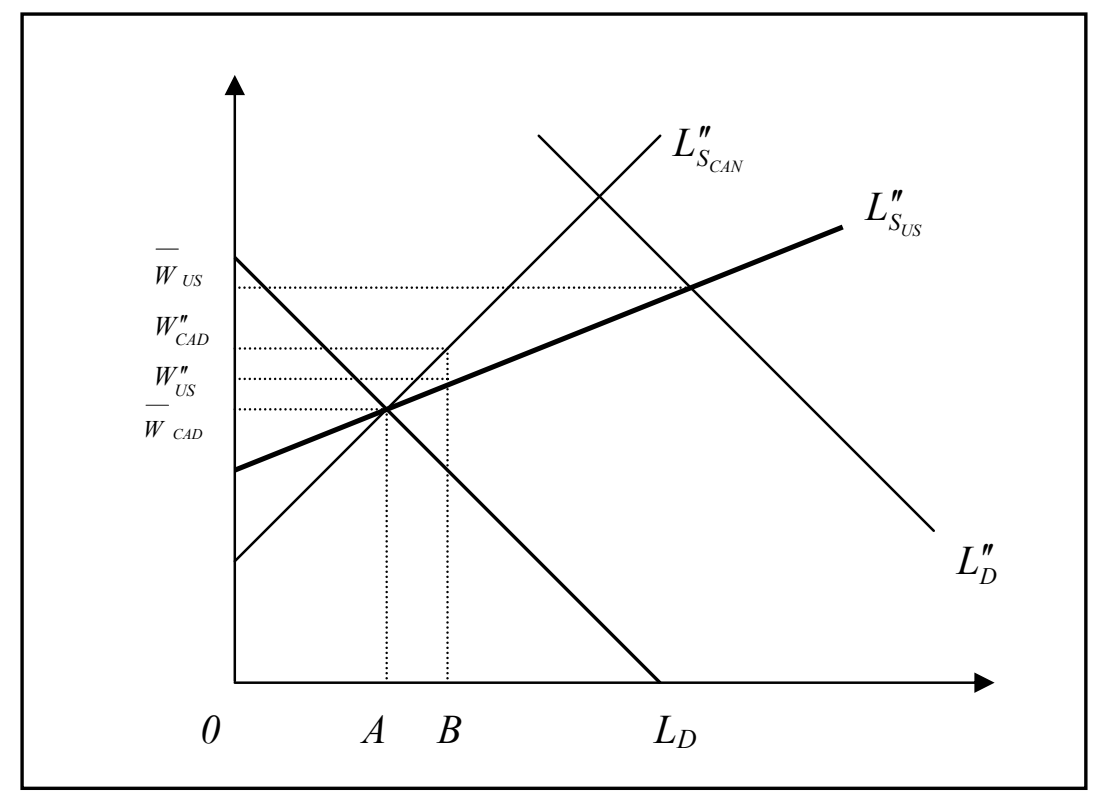

What is the econometric evidence to support either figure 7 or 8 ? Is there a neutral (Figure 7) or a negative (Figure 8) job displacement effect? The United States evidence is dated (Grossman, 1982) but it suggests immigrant-, native-born labour substitution. The more modern Canadian evidence is mixed. In the Canadian context Akbari and DeVoretz (1992) report results for the 1980s supporting figure 7 or the neutral case for the economy-wide analysis. However, Laryea (1997) indicates that there exist substantial "churning costs" in the 1990's, since substantial labour displacement occurred in the foreign-born labour-intensive sector while the remainder of the economy experienced job expansion or neutral effects. ${ }^{16}$ The incidence of these "churning costs" is even more complex since newer immigrants tend to substitute for older immigrants, and have little impact on the employment of Canadian-born labour. Thus, in the Canadian context, if the "churning costs" are large, they may offset public finance gains when the Simon Principle is satisfied.

\footnotetext{
${ }^{15}$ We could have eliminated all domestic labour just by lowering the foreign-born wage rate. Given minimum wage laws, this is an unlikely case.

${ }^{16}$ Foreign intensive industries consisted of those industries with 30 per cent or more of their labour force being foreign-born.
} 


\section{Capital Market}

Various countries have explicitly recognized that immigrants can augment the supply of capital in the receiving country. Grubel and Scott (1964) first recognized that highly-skilled immigrants provided a heretofore previously unaccounted inflow of human capital into the receiving countries national accounts. This inflow substantially augmented the trained manpower of some countries in the 1960s and 1970s. However, by the 1980s the inflow of embodied human capital had diminished (Coulson and DeVoretz, 1992). With the rise in the demand for IT workers in Europe and North America in the 1990s, the large net flow of human capital to the United States resumed under the guise of temporary inflows (DeVoretz and Iturralde, 2001). The human capital flow of the late 1990s was no longer a "brain drain" but a "brain exchange" (DeVoretz and Zhang, 2004) ${ }^{17}$, also ultimately beneficial to the sending country. ${ }^{18}$

Immigrant policies in receiving countries have gone beyond the narrow policy of recruiting human capital through immigrants, and now seek financial capital by attracting immigrant investors. In fact, the United States, Germany and Canada have explicit immigrant entry programmes for investors and their families. These require a minimum investment with associated employment guarantees over a set time period before a permanent immigrant visa is issued. The programmes have met with mixed success over the last 15 years. ${ }^{19}$ Globerman (2001) wondered if the invested capital would have arrived without the incentive of an immigrant visa, while Ley (2000) questions the size of, and the benefits derived from, the Canadian programmes.

A more important form of capital accumulation could be owing to immigrant wealth after arrival, and it is argued that two pecuniary externalities may arise in this case. The first externality arises if immigrants accumulate a greater net worth than the native-born. In a closed economy this would lead to a rise in the destination country's capital labour ratio. If the nativeborn population could capture this capital in the form of higher average incomes, then this could be considered an important externality. ${ }^{20}$

The macro growth benefits notwithstanding, the literature has focused on the implications of household wealth accumulation (Shamsuddin and DeVoretz, 1999; Zhang, 2003). Several motives arise in the micro level research agenda, including: bequest, social security provisions, and household risk diversification. In the Canadian case, econometric work shows that inter-vivo transfers and a substantial bequest motive characterize immigrant wealth accumulation. This implies that the Canadian foreign-born accumulate more wealth than the Canadian-born and transfer it to their progeny during their life or at the end of it (Shamsuddin and DeVoretz 1999).

In addition, Canadian immigrants honour the Feldman hypothesis as they have a low rate of substitution between publicly-financed social security and private wealth accumulation indicating that they have a preference to privately finance their retirement. ${ }^{21}$ Further studies must be conducted to see how immigrants react to different institutional settings for wealth accumulation. However, the Canadian evidence indicates that immigrants wealth accumulation after arrival and by the second generation (via education) raises the capital labour ratio in the destination country and may have possible spill over effects on the resident population.

\footnotetext{
17 The use of the TN and H1-B visas in the United States intially blunted any criticism of a resurrection of the brain drain since these visas were explicitly temporary. However, visitors using these visas often converted them into permanent entry visas.

18 In fact, in a series of papers Stark (2003) argues that human capital outlflows from poor countries create a positive externality in the sending country. This occurs under a strict set of conditions. To wit, if the human capital flow is restricted at the entry point. then the preserved premiums earned by the immigrant's human capital in the destination country act as an added incentive for the potential immigrant to accumulate more human capital in the sending region.

${ }^{19}$ Several studies cited in Ley (2000) have indicated that Canada's investor programme has suffered from fraud both on the borrower and lender sides. In addition, the United States investor programme has proved a limited attraction given its high entry price.

${ }^{20}$ This would hold under a neo-classical growth model view of the world.

21 In general a Feldman life-cycle model predominates in the wealth accumulation literature. This analysis yields a test for the substitution of one tax-financed unit of social security on the immigrant's private net worth. The substitution effect is .19 in the Canadian context (Shamsuddin and DeVoretz, 1999).
} 


\section{Demographic Externalities}

Demographic concerns over population size, population growth rates, and changing age structures are obviously related to immigration policy. Simon's research agenda captured the overlapping relation between immigration, population size, and economic growth when he argued that the demographic forces had a positive impact on economic development. In this essay we trace the economic externalities created by the demographic impact of immigration. These include, scale economies, pressures for innovation, and the smoothing of age-specific labour force shortfalls owing to a collapse in crude birth rates. The potential relationship between immigration and scale effects has a long history in the immigration literature. New world economic historians Williamson et al. (1993), Timlin (1951) and Kelly (1965) have pointed to intensity and scale issues with respect to European immigration flows to the United States, Canada and Australia respectively. ${ }^{22}$

Given the large land masses of these newly settled regions and the inflow of European capital, labour scale economies could result which would in turn raise the average productivity of all inputs and hence income per capita. In the historical setting the argument was subtler since notions of market size and pressures for innovation also appeared as a by-product of increased population size through immigration. ${ }^{23}$ A second and more cogent economies-of-scale argument relates population size through immigration with market size. In the Canadian context, a debate over increasing market size through freer trade or increased number of immigrants has persisted for a century, last appearing the early $1990 \mathrm{~s} .{ }^{24}$ One rationale for Canada joining NAFTA was to increase market size and enjoy scale economies without having to increase population densities to the size of its Mexican and American partners through immigration.

In sum, economic arguments for immigration seem merely speculative compared to the current demographic argument that immigration flows can supply workers in demographically challenged countries. A United Nations (2002) study suggested that more open immigration could supplement negative labour force growth in western European countries and Japan. The economic rationale in this study was two-fold. First, immigrants could lower the dependency ratio, and, secondly, immigrants could provide semi-skilled labour to care for an aging population. The effectiveness of using immigration to forestall a decline in the dependency ratio has not been established. The sheer numbers of immigrants involved to offset the decline in the dependency ratio would be beyond the capacity of most countries to absorb

The Japanese in particular have addressed the issue of integration and the need for semiskilled labour to cope with an aging population. In the 1990s the Japanese imported ethnic Japanese immigrants from South America with mixed success (Tanimura, 2000). ${ }^{25}$

\section{Other Pecuniary Externalities}

Redistributive effects on relative factor and goods prices may arise from the presence of immigrant labour. Figure 7 illustrated how returns to labour are influenced by the presence of immigrants, as native wages declined and returns to capital grew in the face of static labour demand in an immigrant-receiving sector. Under static conditions the price of labour-intensive

\footnotetext{
${ }^{22}$ Williamson et al.(1993) argue that labour and capital were scarce in North America and land was abundant. Hence, the fact that capital and labour moved to North America in the 19th century altered both the technology chosen and the relative factor reward payment for labour.

${ }^{23}$ For example, Simon (1977) argued that innovation was spawned by population pressures to overcome declining productivity in the face of growing population size owing to a natural population increase or immigration.

24 The Economic Council of Canada (1991) argued against immigration and said that scale economies could be enjoyed through a free-trade association such as NAFTA.

${ }^{25}$ Tanimura(2000) cites language problems as an impediment to integration, and also notes that the numbers of Nikkeijin actually needed to make up for the Japanese demographic shortfall is so large that the potential supply of Nikkeijin would be quickly exhausted.
} 
goods, or more likely services, will decline in immigrant-intensive sectors. This latter effect will raise the consumer surplus of these immigrant-intensive goods or services. However, recent research has also noted that immigrants may have diverse demand or taste patterns, and may adversely affect the domestic price of non-tradables, such as that of housing in immigrantreceiving urban centres. ${ }^{26}$ However, on balance it is difficult to estimate the change in consumer surplus owing to immigration, since some non-tradable goods will experience a price increase while other labour-intensive service prices may decline.

\section{Immigrant Economic Criteria: "Catch-up"}

Social and economic integration go hand in hand. The Simon Principle is central to measuring economic integration of immigrants. But what measures are available for the immigrants to self-assess their degree of integration? Are such measures absolute or relative to some reference group; in turn, are reference groups found in the neighbourhood or in a wider social space? Finally do the self-assessed integration measures vary over time for the immigrant?

For the last thirty years economists have employed the relative income measure depicted in Figure 9 and owing to Chiswick (1978) to assess the degree of immigrant integration over time.

\section{Figure 9: Theoretical "Catch-up"}

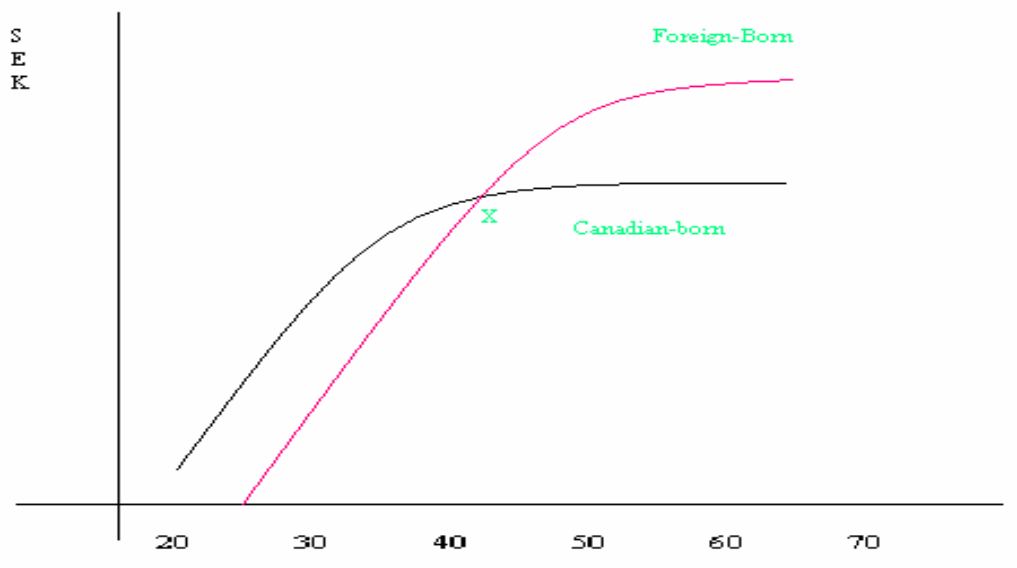

The central question in the immigrant's mind centres around the time it will take to "catch-up" to the reference group's income level. Figure 9 illustrates the stylized nature of the immigrant earnings "catch-up". If the immigrant enters at age 27, initial earnings will lie below the native-born cohort. According to this optimistic diagram, 15 years pass and the immigrant then "catches up" to the native-born earnings at point x. After accumulating country specific human capital, the immigrant will outperform the relevant native-born cohort. One question often asked is, why should there be a period of "catch-up", especially if the immigrant has been screened for human capital? Economists speculate that immigrants must equip themselves after arrival with country-specific human capital, and must learn networking techniques to achieve labour market mobility. We now turn to some North American and European evidence to substantiate immigrant economic integration based upon the concept of the "catch-up".

\footnotetext{
${ }^{26}$ See Didukh (2001) for a study of housing in the Canadian context
} 


\section{A. Sweden}

Sweden has had two distinct inflows of foreigners. Nordic economic immigrants from Norway and Finland arrived in Sweden in the 1960s to 1980s. Then refugees from Iran, Iraq and the former Yugoslavia arrived in the 1990s with different skills and linguistic background. Figure 10 portrays the actual age income plots for these Swedish foreign-born populations in 2001. The Finnish economic immigrants who arrived in the 1970s closely mimic the income performance of the Swedish population while never reaching the "crossover" point with the Swedish population.

Figure 10: Swedish Average income for Employed by age and Foreign-birth Status in 2000 (SEK 2000)

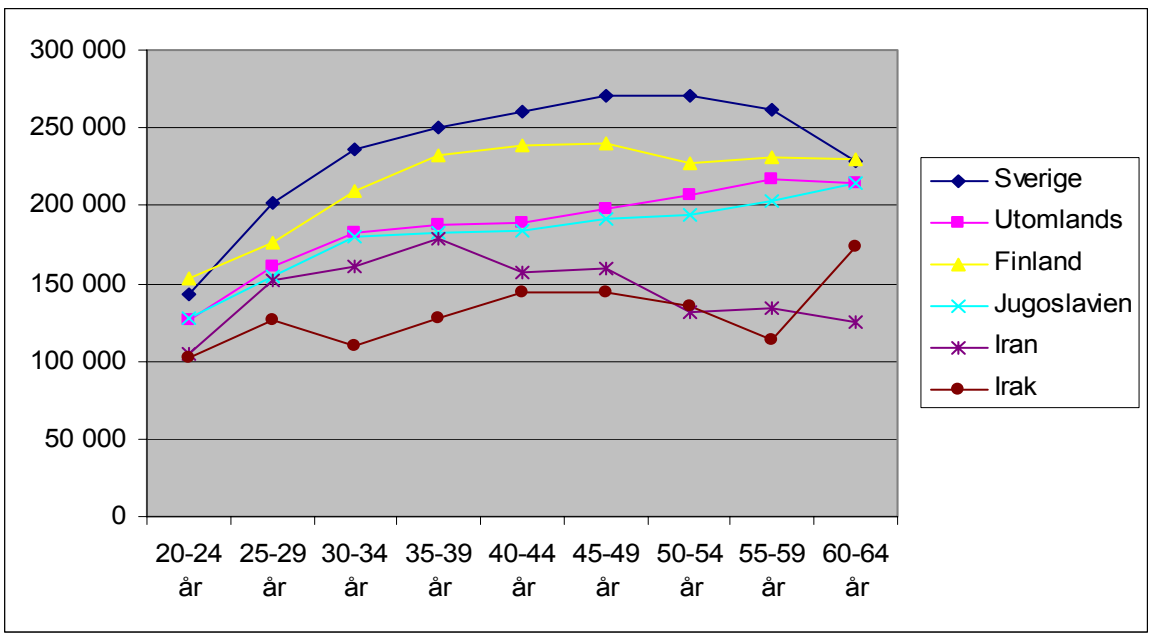

There exists however a substantial and persistent income gap across the life cycle of the various recent refugee populations and the Swedes. During the key income earning years ranging from 35 to 55 years of age, the income gap for Iranian or Iraqi refugees in Sweden widens to 45 $\%$ with respect to the Swedish-born population. In sum, at least since the 1990s the Swedish foreign-born age-income experience on average indicates little income integration.

The self-assessment by Swedish immigrants of their degree of economic integration is actually more complicated then the simple portrayal of an age-earnings profile. Rooth (1999) and Bevelander (2000) correctly note that integration into the Swedish labour market is a two-stage process. First, refugees must get a job and then the earnings assimilation will portray their ultimate degree of integration. All the available evidence suggests that Swedish refugees experience double jeopardy, namely, they suffer inordinately low rates of employment as well as reduced earnings if they are employed as depicted in figure 10. In fact, Bevelander (2000) reports a collapse in Swedish immigrant employment rates after 1975 (Figure 11), culminating in a less than 60 percent employment rate in the late 1990s. Thus, for modern Swedish refugees the concept of an income "catch-up" is irrelevant since employment integration has yet to occur. 
Figure 11: Swedish Employment Rates by Birth Status: 1960-1995

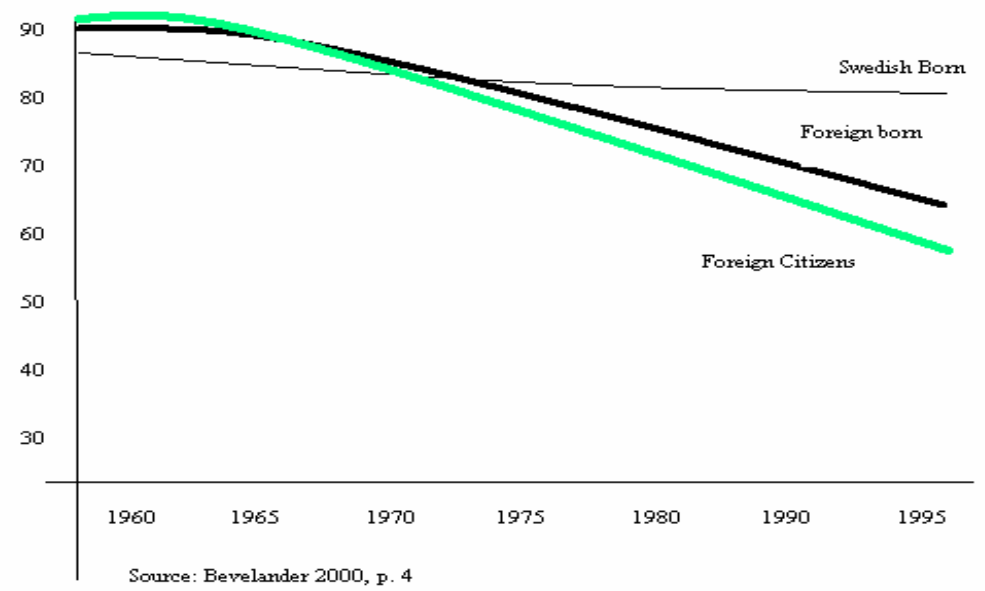

Swedish immigrants would conclude from both their employment (Figure 11) and earnings experience that by the $21^{\text {st }}$ century there is no "crossover" point owing to a substantial "catch-up" effect.

\section{B. Germany}

The earnings assimilation hypothesis has been tested in the modern German context. Germany's immigrant population circa 1998 consisted of ethnic Germans from Eastern Europe ( 2.5 million), southern European immigrants from the EU (3 million) and others, representing $12 \%$ of the German population. Figure 12 portrays Lang's (2000) simulated earnings assimilation for the foreign-born German worker and never depicted a "crossover" point. However, ascension to citizenship reduced the lifetime income gap of $16 \%$ to approximately one-half that level, or 9\%. Lang (2000) however reported a "catch-up" in earnings for ethnic German citizens after 17 years of residence in Germany. ${ }^{27}$

\section{Figure 12: Frontier Earnings Functions of Inhabitants and Immigrants}

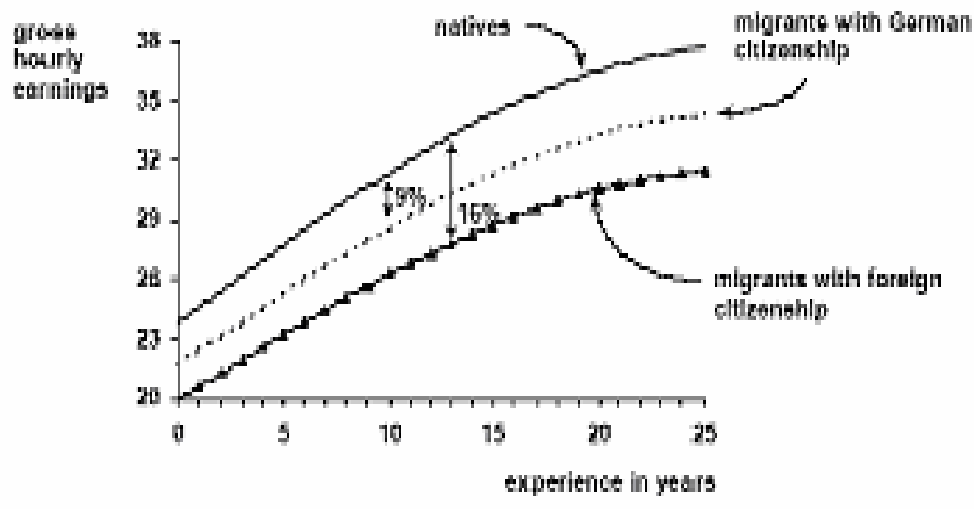

27 Constant and Massey, (2003) report an earnings crossover for German guest workers but only after 24 years in residence. 
In sum, the German and Swedish examples offer little evidence of immigrant labour market assimilation in terms of either employment or earnings.

\section{Canada}

Canadian research allows a more detailed portrayal of immigrant income assimilation experience. Figure 13 portrays a series of cross-sectional age-earnings profiles for two of the largest foreign-born groups, the Chinese and the British, in Canada circa $1996{ }^{28}$ The profiles are intended to be a reference map for Chinese or British immigrants vis-à-vis Canadians when either immigrant group self-assesses its degree of labour market integration into the Canadian labour market. $^{29}$

From figure 13 it is clear that British immigrants before or after obtaining citizenship would conclude that they were integrated into the Canadian economy. In fact, British immigrants to Canada do not suffer an earnings penalty upon arrival. After ascension to citizenship, the British become overachievers relative to the Canadian-born. On the other hand, regardless of citizenship status the Chinese would not feel integrated. In fact, Chinese immigrants without citizenship earn less than $50 \%$ of the Canadian-born cohort throughout their lifetime. Ascension to citizenship for Chinese immigrants removes most of this income disparity. ${ }^{30}$

Figure 13: Age-earnings profiles for the Canadian-born (CB), British Immigrants

Canadian citizens (BritIm_C) and non-citizens of Canada (BritIm_NC), Chinese Immigrants Canadian citizens (ChinIm_C) and non-citizens of Canada (ChinIm_NC)

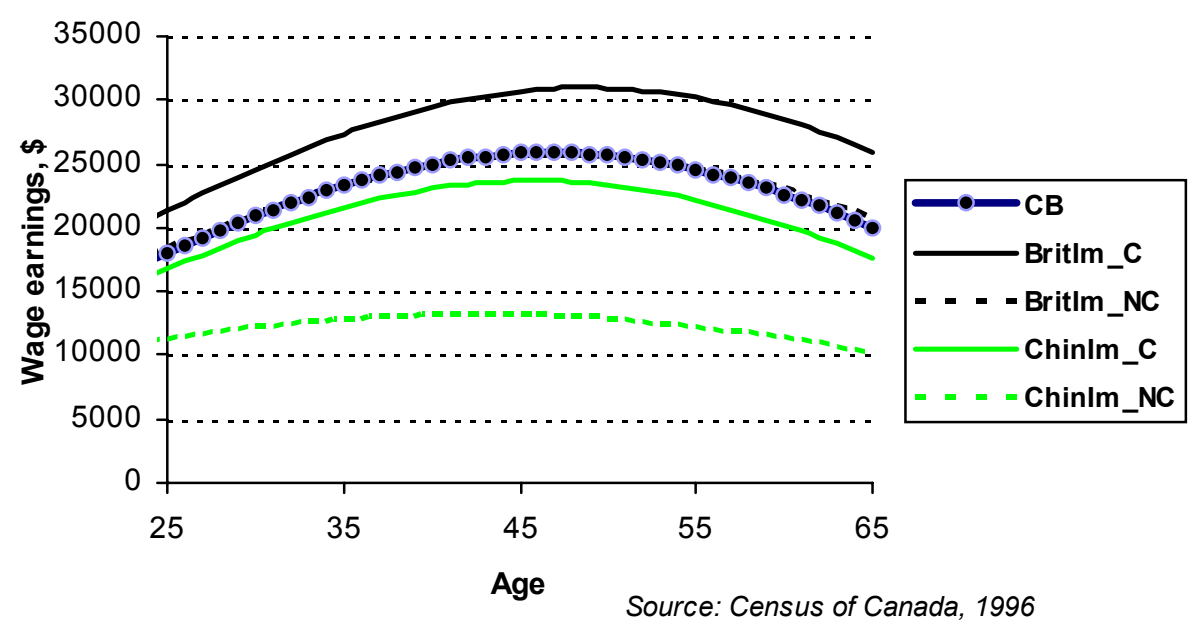

Figure 14 reports a similar set of findings for another paired set of under- and overachieving immigrants. Immigrants from the Ukraine who never ascend to Canadian citizenship only reach a "crossover" point in earnings at age 62. However, Ukrainian immigrants who become citizens equalize their earnings immediately and exceed the Canadian-born cohort after age $45 .^{31}$

\footnotetext{
${ }^{28}$ I concede that these cross-sectional snapshots could be biased and that longitudinal data would be preferable.

${ }^{29}$ Figures 10 and 11 are generated by raw data.

30 The citizenship effect is owing to positive self-selection of citizens and a wider labour market for citizens.

31 Again, I note that self-selection may play a role in the ascension to citizenship, and thus only the highly motivated may become citizens.
} 
Figure 14: Age-earnings profiles for Ukrainians Canadian Born (UCB), Ukrainian Immigrants Canadian citizens (UI_C) and Ukrainian Immigrants non-citizens of Canada (UI_NC)

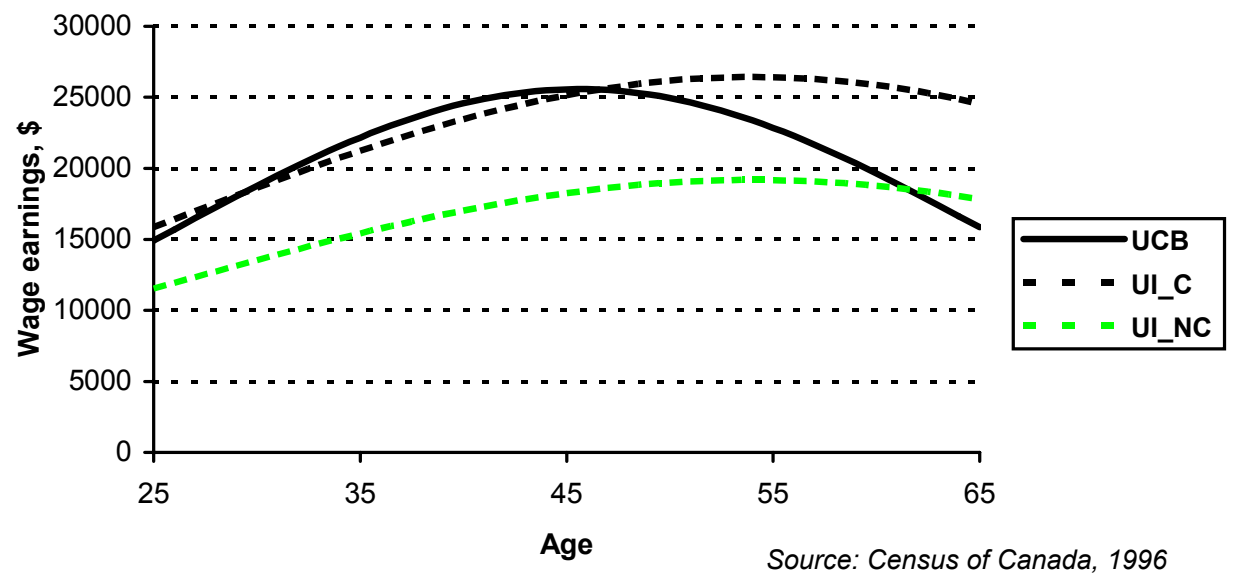

In sum, in Canada earnings assimilation occurs upon arrival for the overachieving group of entrants (British, United States, Italian, and German immigrants), while ascension to Canadian citizenship insures assimilation for the Chinese and Ukrainians.

\section{United States}

Immigrant age earning profiles and the associated "crossover" measures have a long history in the United States literature starting with Chiswick (1978). A more modern illustration by Pivnenko and DeVoretz (2004) parallels the Canadian findings and illustrates again the diversity of results. In figure 14, three age-earnings profiles are reported for Ukrainian immigrants (UI_US), all other immigrants (NUI_US) and the native-born in the United States (NUUSB) in $2000 .^{32}$ The Ukrainians are truly "overachievers" in the United States, as they do not experience an earnings penalty upon arrival; hence the concept of the "crossover" point is irrelevant. This contrasts with the "crossover" point only occurring at the end of the working life of the foreign-born population.

\footnotetext{
${ }^{32}$ For purposes of this experiment NUSSB is native-born Americans net of native-born ethnic Ukrainians.
} 
Figure 15: Age-earnings profile for Ukrainian Immigrants to the U.S. (UI_US), NonUkrainian Immigrants to the U.S. (NUI_US), Ukrainian U.S. born (UUSB), and NonUkrainian U.S. born (NUUSB)

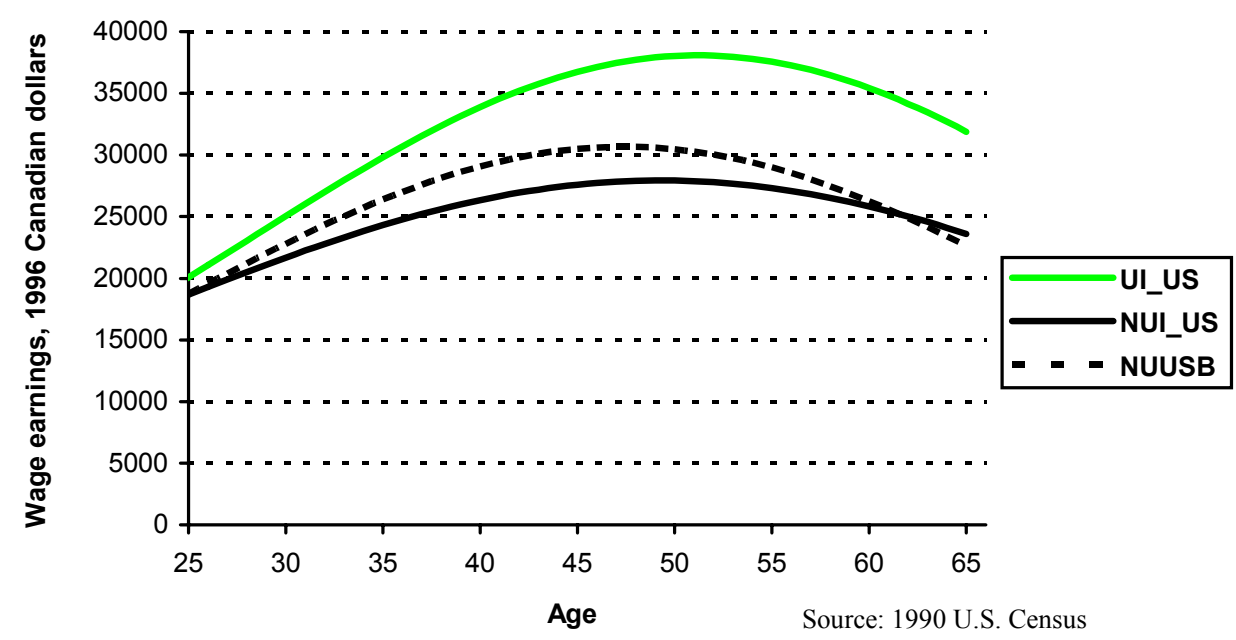

In sum, these four case studies allow some limited generalizations about the degree of earnings assimilation for the recent immigrant stocks in Sweden, Germany, Canada and the United States. First, in all the examples the actual data reproduced the familiar concave earnings functions predicted by a human capital model.$^{33}$ Next, most immigrants, regardless of origin or destination suffered an earnings penalty upon arrival, as originally predicted by Chiswick (1978). In addition, in most of the reported cases, employed immigrant and refugee earnings rose over time, with only a few cases in which the foreign-born "catch-up" to the native-born. These rare cases usually include an act of ascension to citizenship in the relevant country. ${ }^{34}$ Thus, to the extent that immigrants use the "catch-up" measure as a metric for economic assimilation, most, but clearly not all, modern immigrants must conclude that they will never economically assimilate.

What has been the reaction of those immigrants who have not assimilated in terms of the "catch-up"? A limited number of studies indicate that some disappointed Canadian immigrants who have not economically assimilated have returned home and actually outperformed their cohort who stayed (DeVoretz et al., 2003). In other cases, disappointed highly-skilled Canadian immigrants have moved to the United States (DeVoretz and Iturralde, 2001). However, the majority of the immigrants who did not assimilate remained in Canada; interviews indicate that they hope that their children will successfully assimilate. ${ }^{35}$

\section{Origin Country Economic Assessment Criteria}

China, India, the Philippines, and a host of smaller immigrant-sending countries have historically critically judged Canadian, Australian and United States immigration policies as

\footnotetext{
33 All the reported age-earnings profiles except Lang (2000) are from raw data and not fitted, so that concave curve is not an outgrowth of a simulation excercise with fitted data fitted to a quadratic human capital model.

34 Only the British and United States immigrants in Canada, and Ukainians in the United States did not have to ascend to citizenship to experience the earnings "crossover".

35 Although the performance of the second generation, and even the so called 1.5 generation, is beyond the scope of this work, it may be the ultimate measure of the economic assimilation that the first wave of unsuccessful immigrants use as the true metric of economic assimilation.
} 
harmful to their development. The highly-skilled outflows from these countries and the small or non-existent number of returnees led to accusations of a "brain drain" until the late 1980s (Coulson and DeVoretz, 1993). With the advent of temporary highly skilled worker visas in North America and Europe, these criticisms became more muted as the concept of "brain circulation" replaced the brain drain rhetoric. ${ }^{36}$

Other immigrant-related phenomena helped mute the criticism levelled at receiving countries by sending countries. While historically important for a few countries (The Philippines, Pakistan, and Mexico), immigrant remittances became more pronounced in 2001 when US 73 billion dollars was remitted primarily from the United States, Saudi Arabia and Germany. In fact, immigrant remittances had exceeded official development assistance by 2002 , and equalled $42 \%$ of total foreign direct investment to less developed countries (Straubhaar and Vadean, 2004). In addition, India, Hong-Kong, Taiwan, and China experienced immigrant-induced foreign direct investment, remittances and return migration to spur their development. As a result of the "brain circulation" and of the size of remittances, source countries have developed programmes and policies to attract their people back.

Dual citizenship may have been the most important instrument to encourage brain circulation and remittance investments (DeVoretz and Zhang, 2004). In 2003, India instituted a partial dual citizenship policy allowing its dual nationals to return and work or invest in India whilst maintaining their acquired citizenship. ${ }^{37}$ China has been more hesitant and has instituted a so-called "green card" issued only to encourage erstwhile Chinese citizens to return and work indefinitely as a foreign national in a particular Chinese city. ${ }^{38} \mathrm{In}$ order for these dual citizenship policies to work to the benefit of the immigrant, destination countries must also recognize dual citizenship. Amongst the major ones, only Canada and Australia have a clearly defined dual citizenship policy. ${ }^{39}$

In addition, immigration policies of destination countries affect the size of remittance flows. Legal or illegal temporary unskilled immigration and admission of political refugees appear to be pre-conditions to generate substantial remittances by the unskilled. However, permanent immigrant status coupled with a generous family reunification policy, such as Canada's, lowers levels of remittances that often terminate after 5 to 10 years (DeVoretz, 2004). In sharp contrast, Mexican temporary workers in the United States have remitted large and growing sums under an imaginative Mexican matching scheme (Aescobar, 2004).

To summarize, major immigrant-sending regions, especially China, Mexico and India, have reassessed their critical appraisal of first-world immigration policies given the rise in remittances, return migration, and foreign direct investment by returned émigrés. However, it would be premature to conclude that immigrant-sending regions assess emigration as a mean of improving their economy.

\section{Summary and Conclusions}

The aim of this paper was to seek economic principles to evaluate immigration policy regimes from various points of view. From the resident's viewpoint an expanded version of the Simon Principle was argued to constitute an assessment criterion of an immigration policy. The

\footnotetext{
${ }^{36}$ The H1-B visa in the United States and the so-called German "Green KortCard" were specifically designed to attract highly skilled immigrants for a limited period of time. The number of H1-B conversions from temporary to permanent were substantial and the German "Green KortCard", while temporary, did not attract many highly skilled immigrants. In addition, Canada and Australia continued to use their permanent entry gates to attract highly skilled immigrants throughout the 1990s.

${ }^{37}$ India maintains political restrictions on dual citizens since they can not vote in Indian elections.

${ }^{38}$ China still treats erstwhile Chinese citizens as foreign nationals with a series of differential fees and restrictions on use of social services, especially their children's access to Chinese education.

39 In the United States dual citizenship is permitted but not automatic. In addition, the United States taxes its citizens' world-wide income, a clear disincentive for continuous brain circulation.
} 
immigrant's impact on the residents' welfare via public finance transfers, employment, scale economies and goods prices constituted this set of economic criteria. Examples from Europe and North America illustrated the feasibility of measuring the public finance and employment impacts. An argument was made that a net economic transfer criterion could be applied to evaluate any country's immigration policy. Thus, public finance transfers net of any "churning costs" associated with labour displacement would serve as the evaluation criterion from the resident's viewpoint in the receiving country.

The immigrant's economic assessment criteria were based on the ability to "catch-up" in terms of employment and earnings within a life cycle model. Again, evidence was presented in both the European and North American contexts to illustrate the feasibility of these selfassessment "catch-up" measures. In addition, the sending country's economic assessment criteria for a destination country's immigration policy was argued to include, the magnitude of brain circulation, remittances and return migration cum foreign direct investment resulting from the initial outflow of immigrants.

Finally, both nation states and immigrants themselves react to economic evaluations of their immigrant experiences in an asymmetrical fashion. When the economic evidence is unfavourable, immigration policies become more restrictive but only a minority of immigrants leave. On the other hand, when the Simon Principle is satisfied, few, if any, countries rapidly expand their immigration numbers to recognize this fact.

There are several possible reasons for this hesitant response. First, there is risk aversion. If the Simon Principle appears to be satisfied in the short, but not the long run, immigration expansion becomes too risky since immigrants cannot be sent back home. Secondly, economic principles are not the only admission criterion; a lingering concept of social cohesion or absorptive capacity always negates the implications of a positive economic assessment on a country's immigration policy. This is especially true in republican states such as France, or ethnic groupings such as pre-1989 Germany. 


\section{$\underline{\text { References }}$}

Aescobar, A. (2004) Migration and the Diaspora. Proceedings of Migration and Development: Working with the Diaspora. Geneva: International Labour Organization.

Akbari, A. H. (1995) The Impact of Immigrants on Canada's Treasury, Circa 1990. In D. J. DeVoretz (Ed.), Diminishing Returns, 113-127. Toronto: C.D. Howe Institute and Vancouver: The Laurier Institution.

Akbari, A. H. \& DeVoretz, D. J. (1992) The Substitutability of Foreign born Labour in Canadian Production: Circa 1980. Canadian Journal of Economics, 25 (3): 604-614.

Bevelander, P. (2000) Immigrant Employment Integration and Structural Change in Sweden: 1970-1995. Lund Studies in Economic History \#15. Lund: Lund University Press.

Borjas, G. (2003) Welfare Reform and Immigrant Participation in Welfare Programs. In J. G. Reitz (Ed.), Host Societies and the Reception of Immigrants, 289-325. San Diego: Center for U.S.-Mexican Studies, University of California.

Chiswick, B. R. (2000) The Economics of Illegal Migration for the Host Economy. RIIM Working Paper 00-11. Burnaby: RIIM, Simon Fraser University.

(1978) Americanization and the Earnings of Foreign-born Men. Journal of Political Economy, 86 (5): 897-921.

Constant, A. \& Massey, D. (2003) Labor Market Segmentation and the Earnings of German Guest workers. IZA DP No. 774. Bonn: IZA.

Coulson, R. \& DeVoretz, D. J. (1993) Human Capital Content of Canadian Immigration: 19661987. Canadian Public Policy, 19 (4): 357-366.

DeVoretz, D. J. (2004) Canadian Immigrant Monetized Transfers: Evidence from Micro Data Proceedings of Migration and Development: Working with the Diaspora. Presented at the International Labour Organization, Geneva, February 24.

DeVoretz, D. J. \& Iturralde, C. (2001) Why do highly skilled Canadians stay in Canada? Policy Options, 59-63.

DeVoretz, D. J. \& Laryea, S. A. (1998) Migration and the Labour Market: Sectoral and Regional Effects in Canada. In Migration, Free Trade and Regional Integration in North America, OECD Proceedings, 135-153.

DeVoretz, D. J., Ma, J. \& Zhang, K. (2003) Triangular Human Capital Flows: Some Empirical Evidence from Hong Kong. In J. G. Reitz (Ed.), Host Societies and the Reception of Immigrants. San Diego: Center for U.S.-Mexican Studies, University of California.

DeVoretz, D. J. \& Pivnenko, S. (2004) The Economics of Canadian Citizenship. Presented at workshop on Immigrant Ascension to Citizenship. IMER, Malmo University, June 7.

DeVoretz, D. J. \& Zhang, K. (2004, Forthcoming) Citizenship, Passports and the Brain Exchange Triangle. Journal of Comparative Policy Analysis. 
Didukh, G. (2002) Immigrants and the Demand for Shelter. RIIM Working Paper 02-01. Burnaby: RIIM, Simon Fraser University.

, (2001) Health and Personal Care Consumption Patterns of Foreign-born and Canadian-born Consumers: 1984-1996. RIIM Working Paper 01-13. Burnaby: RIIM, Simon Fraser University.

Economic Council of Canada (1991) New Faces in the Crowd: Economic and Social Impacts of Immigration. Ottawa: Supply and Services Canada.

Geiger, B. (2002) Clothing Demand for Canadian-born and Foreign-born Households. RIIM Working Paper 02-04. Burnaby: RIIM, Simon Fraser University.

Globerman, S. (2001) Globalization and Immigration. RIIM Working Paper 01-S2. Burnaby: RIIM, Simon Fraser University.

Grossman, J. B. (1982) The substitutability of natives and immigrants in production. Review of Economics and Statistics, 64: 596-603.

Grubel, H. \& Scott, A. (1966) The International Flow of Human Capital. American Economic Review, 56 (2): 268-274.

Gustafsson, B. and Österberg, T. (2001) Immigrants and the public sector budget-accounting. Journal of Population Economics, 14 (4): 689-708.

Kelley, A. C. (1965) International Migration and Economic Growth: Australia, 1865-1935. The Journal of Economic History, 25 (3): 333-354.

Lang, G. (2000) Native-Immigrant Wage Differentials in Germany - Assimilation, Discrimination, or Human Capital?. Institute for Economics Discussion Paper \#197. Augsburg: Universitaet Augsburg.

Laryea, S. A. (1997) Estimating the Impact of Foreign-Born Labour on Wage Rates in Canada. Unpublished Ph.D. Dissertation, Department of Economics, Simon Fraser University, Burnaby.

Ley, D. (2000) Seeking 'Homo Economicus': The Strange Story of Canada's Business Immigration Program. RIIM Working Paper 00-02. Burnaby: RIIM, Simon Fraser University.

Lofstrom, M. \& Bean, F. D. (2002) Assessing Immigrant Policy Options: Labor Market Conditions and Post Reform Declines in Immigrant Receipt of Welfare. Demography, 39 (4): 617-637.

Pivnenko, S. \& DeVoretz, D. J. (2004) Immigrant Public Finance Transfers: A Comparative Analysis by City. Canadian Journal of Urban Research, 13 (1): 155-169.

(2003) The Recent Economic Performance of Ukrainian Immigrants in Canada and the U.S. RIIM Working Paper 03-10; Burnaby: RIIM, Simon Fraser University, and IZA DP No. 913. Bonn: IZA. 
Rooth, D. (1999) Refugee Immigrants in Sweden, educational investments and labour market integration. Unpublished Ph.D. Dissertation, Lund Economic Studies \#84. Lund: Lund University.

Shamsuddin, A. \& DeVoretz, D. J. (1999) Wealth Accumulation of Canadian and Foreign-born Households in Canada. Review of Income and Wealth, 44 (4): 515-553.

Sicakkan, H.G. (1999) The Political-Historical Roots of West European Models of Citizen and Alien: An Application of Qualitative Comparative Analysis on Macro Historical Data. IMERNorway/Bergen Publications.

Simon, J. (1977) The Economics of Population Growth. New York: Princeton University Press.

(1984) Immigrants, Taxes and Welfare in the United States. Population and Development Review, 10 (1): 55-69.

(1996) Public Expenditures on Immigrants in the United States, Past and Present. Population and Development Review, 22 (1): 99-109.

Simon, J. \& Akbari, A. H. (2000) The Effects of Immigrants on the German Public Purse. In A.M. Babkina (Ed.), Politics of Immigration: Current Issues and Future Directions, 219-241. New York: Nova Science Publishers.

Smith, J. P. \& Edmondson, B. (1997) Do immigrants impose a net fiscal burden? Annual estimates. In J. P. Smith and B. Edmondson (Eds.), The new Americans: Economic, demographic and fiscal effects of immigration, 254-296. Washington, D.C.: National Academy Press.

Stark, O. (2003) Rethinking the Brain Drain. World Development, 32 (1): 5-22.

Straubhaar, T. \& Vadean, F. (2004, Forthcoming) International Migrant Remittances and their Role in Development. OECD.

Straubhaar, T. \& Weber, R. (1994) On the Economics of Immigration. International Review of Applied Economics, 8: 107-129.

Tanimura, C. (2000) Temporary Immigration of Nikkeijin to Ease the Japanese Aging Crisis. RIIM Working Paper 00-03. Burnaby: RIIM, Simon Fraser University.

Timlin, M. (1951). Does Canada Need More People? Oxford: Oxford University Press.

United Nations (2000) Replacement Migration: Is It a Solution to Declining and Aging Populations? Population Division, ESA/P/WP.160.

United Nations (2002) International Migration Report 2002. Population Division, ESA/P/WP.178.

Wang, L. (2001) Household Operations and Furnishings Consumption Patterns of Canadian and Foreign-born Consumers: 1984-1996. RIIM Working Paper 01-18. Burnaby: RIIM, Simon Fraser University. 
Werner, C. (2000) A Taste of Canada: An Analysis of Food Expenditure Patterns for Canadianborn and Foreign-born Consumers. RIIM Working Paper 00-05. Burnaby: RIIM, Simon Fraser University.

Williamson, J. G., O'Rourke, K. H. \& Hatton, T. J. (1993) Mass Migration, Commodity Market Integration and Real Wage Convergence: The Late Nineteenth Century Atlantic Economy. National Bureau of Economic Research Working Paper H0048.

Zhang, X. (2003) The wealth position of immigrant families in Canada. Analytical Studies Branch research paper series. Statistics Canada, Cat. No. 11F0019MIE-No. 197. 